\title{
An Investigation of Social Safety Net Programs as Means of Poverty Alleviation in Bangladesh
}

\author{
Mohammad Abdul Hannan Pradhan ${ }^{1}$, Saidatulakmal Mohd ${ }^{1} \&$ Jamalludin Sulaiman ${ }^{1}$ \\ ${ }^{1}$ School of Social Sciences, Universiti Sains Malaysia, Penang, Malaysia \\ Correspondence: Mohammad Abdul Hannan Pradhan, School of Social Sciences, Universiti Sains Malaysia, \\ Penang 11800, Malaysia. Tel: 60-16-439-5860. E-mail: pradhanhannan@gmail.com
}

Received: November 6, 2012

Accepted: December 1, 2012 Online Published: January 28, 2013

doi:10.5539/ass.v9n2p139

URL: http://dx.doi.org/10.5539/ass.v9n2p139

\begin{abstract}
Bangladesh is a developing and poorer country in the world. The 2010 Household Income and Expenditure Survey (HIES) indicates around 31.6 percent of its population lives under the national poverty line. This has led to the implementation of many social safety net (SSN) programs to address the issue of poverty. In the fiscal year 2009/10, the Bangladesh government allocated 15.22 percent of total budget for SSN program that accounts to 2.52 percent of Gross Domestic Product (GDP). The main objective of this paper is to assess the impact of the SSNs programs on level of poverty reduction in Bangladesh. The study employs time series analysis on the 1996 - 2010 spending on SSN and poverty rate data. Statistical analysis indicates negative relationship between SSN expenditure and poverty rates. This implies that SSNs programs have reached the struggling poor as well as have helped the deprived part of the country's people to pick them up of poverty situation.
\end{abstract}

Keywords: government spending, poverty, social safety net

\section{Introduction}

Bangladesh is a developing and poorer country in the world which is situated in South Asia. The HIES 2010 shows that around 31.6 percent of the country's citizens are under the national poverty line (Bangladesh Bureaue of Statistics [BBS], 2011). Every group has different causes for being poor and each set of underlying aspects implies special remedial measures for poverty reduction. It is argued that poverty along with vulnerability is determined as a result of interactions among personal capacity, characteristics, and peripheral situation. Taking into account of these aspects, the governments of Bangladesh have been making efforts firmly for rapid poverty reduction. At least 84 programs are put into operation in the country for the Fiscal Year (FY) 2010-11 with the help of different Ministries/Divisions. But country wide only 30 major programs have been implementing (Rahman, Choudhury, \& Ali, 2011). Among other programs, cash transfer (conditional and unconditional), food or in-kind transfer, and microfinance are the main. During the period of 2000 to 2005 , the poverty rates reduce from 48.9 percent to 40.0 percent (Finance Division [FD], 2009) and during the period of 2005 to 2010, the poverty rates reduce from 40 percent to 31.50 percent (BBS, 2011). The ruling government of Bangladesh has placed goal to decrease poverty rates to 25 percent and 15 percent by the year of 2013 and 2021, respectively. Consequently the government has allocated 13.32, 15.22, and 14.75 percent of total budget expenses (FD, 2010, 2011), and 2.14, 2.53, and 2.65 percentage of Gross Domestic Product (GDP) for FY 2007-08, 2009-10 and 2010-11 respectively (FD, 2011, 2012). This allocation is seen as small as compared to major industrialized countries those have a group of programs that relocate from 10 to 30 percent of the country's Gross Domestic Product (GDP) along with the population who are close to the underneath of the income-distribution (Kenworthy, 1999).

The ultimate aim of this expenditure on social safety net (SSN) is to reduce poverty rate at rural as well as national level. The SSNs programs have protection and promotion effects on households well being and can play role for poverty reduction (Devereux, 2002; Barrientos, Hulme, \& Shepherd, 2005; Slater, 2011). This subject has been treated as progressively more disputed. Grosh, Del Ninno, Tesliuc and Ouerghi (2008) mentioned that a number of analysts contend that SSN is really of assistance to alleviate poverty. Even when micro credit holders fall into risks, SSN assistance can help to avoid hard core poverty (Mahmud, 2008). Others recommend that giving a safety net benefit, these kinds of programs weaken the inventiveness of the poor people. In that way, a poverty gap can persist for long. Grosh et al. (2008) argued that SSNs cannot be merely adequate elucidation to 
reduce a massive poverty situation; somewhat they may be major share of development policy of the state. Above all, in countries such as Bangladesh where poverty rate is extensive as well as government's financial resources are limited; it needs to know whether the outlay of budget on SSNs is negatively linked with poverty reduction.

The key objective of this paper is to assess the relationship of SSNs expenditure on the level of poverty reduction in Bangladesh. The paper aims to determine whether more amount of SSNs spending is consistent with the lower rates of poverty in Bangladesh. The article is presented into five parts. The next part assesses the poverty situation of Bangladesh, followed by a brief review on the SSNs concepts and programs implemented in Bangladesh. Section four outlines the data and methodology, while section five provides the analysis on the relationship between poverty and SSN expenditure. The final section concludes the paper.

\section{Poverty in Bangladesh}

Different measures carried out by different studies are used as indicator for poverty incidence in Bangladesh. The Household Expenditure Survey (HES) was first carried out in FY 1973-74 after becoming independence. In subsequent years, a number of HESs is carried out. It needs to mention that only information on expenditure is congregated in those surveys. HESs were carried out till 1991-92 are basis on Food Energy Intake (FEI) and Direct Calorie Intake (DCI) technique for measuring the rate of income poverty. An individual having daily calorie intake of less than 2,122 kilocalories is considered to be in absolute poverty or live under the upper poverty line (UPL). On the other hand, a person having daily calorie intake less than 1,805 kilocalories is considered to be in hard-core poverty or living under the lower poverty line (LPL). Beginning with the FY 1995-96, the HES conducted by the Bangladesh Bureau of Statistics (BBS) uses the Cost of Basic Needs (CBN) method. Based on the CBN method, cost of a bundle of goods (food and non-food) is set at a level where members of household are estimated to convene essential requirements. Three steps are followed to estimate the poverty line. First, the cost of fixed food bundle consisting of eleven items (rice, wheat, pulses, milk, oil, meat, fish, potato, other vegetables, sugar, and fruits) providing the minimum nutritional requirements corresponding to $2,122 \mathrm{kcal}$ per day per person is estimated. This cost represents the food poverty line. Second, for the non-food consumption, two non-food allowances are considered. First one is obtained by taking the median amount spent for non-food items by a group of households whose per capita total expenditure is equal to the food poverty line. It is called lower non-food allowance. Second one is obtained by taking the median amount spent for non-food items by a group of households whose per capita food expenditure is equal to the food poverty line. It is called upper non-food allowance. Third, lower poverty line estimated by adding food poverty line with lower non-food allowance and upper poverty line (UPL) is estimated by adding food poverty line with upper non-food allowance. According to Ravallion and Sen (1996 as cited in BBS, 2011) CBN method is more representative and consistent.

Based on the DCI method, the poverty incident registers a reducing tendency in 2000, along with 2005 as compared to 1988, 1991, and 1995. At the national stage, the rate of absolute poverty incident declines from about 48 percent in 1988 to 40.40 percent in 2005 as shown in Table 1.

Table 1. Poverty trends base on DCI technique (headcount ration)

\begin{tabular}{lll}
\hline Year & $\begin{array}{l}\text { Absolute poverty, daily calorie intake below } \\
2,122 \text { Kilocalorie food intakes (\%) }\end{array}$ & $\begin{array}{l}\text { Hardcore poor, daily calorie intake below } \\
1,805 \text { kilocalorie food intakes (\%) }\end{array}$ \\
\hline 1988 & 47.7 & 28.4 \\
1991 & 47.5 & 28 \\
1995 & 47.5 & 25.1 \\
2000 & 44.3 & 20 \\
2005 & 40.4 & 19.5 \\
\hline
\end{tabular}

Source: Food and Agriculture Organization, (food securityaltas.org/ bgd /country/access/food-poverty)

Under the DCI method, a reduction rate of absolute poverty was recorded at $4.1 \%$ from 2000 to 2005 . People living below the poverty line in 2000 were 55.8 million, which increased to 56 million in 2005. (Poverty rate as $\%$ of total population declined but total number of poor people increased due to high growth rate of population).

Under the CBN method, the incidence of population living under the upper poverty line decreases from 53.08 percent in FY 1995-96 to 48.90 percent in FY 2000-01. During the mentioned period, yearly the composite 
reduction rate of poverty is found at 1.8 percent. Conversely, in FY 2000-05, poverty rate reduces further to 40 percent with compound reduction rate of 3.9 percent. The poverty rates reduced further during FY 2010-11 to 31.5 percent. A resembling downward tendency is as well profound for percentage of population living under the lower poverty line. In general, regardless of the method used, the poverty rates in Bangladesh have dropped remarkably as shown in Table 2 and Figure 1.

Table 2. Poverty trend based on CBN technique (Headcount ratio)

\begin{tabular}{lll}
\hline year & Upper poverty (\%) & Lower poverty (\%) \\
\hline $1995-96$ & 53.08 & 35.55 \\
$2000-01$ & 48.90 & 34.30 \\
$2005-06$ & 40.00 & 25.10 \\
$2010-11$ & 31.5 & 17.60
\end{tabular}

Source: Bangladesh Bureau of Statistics, 2005 and 2010.

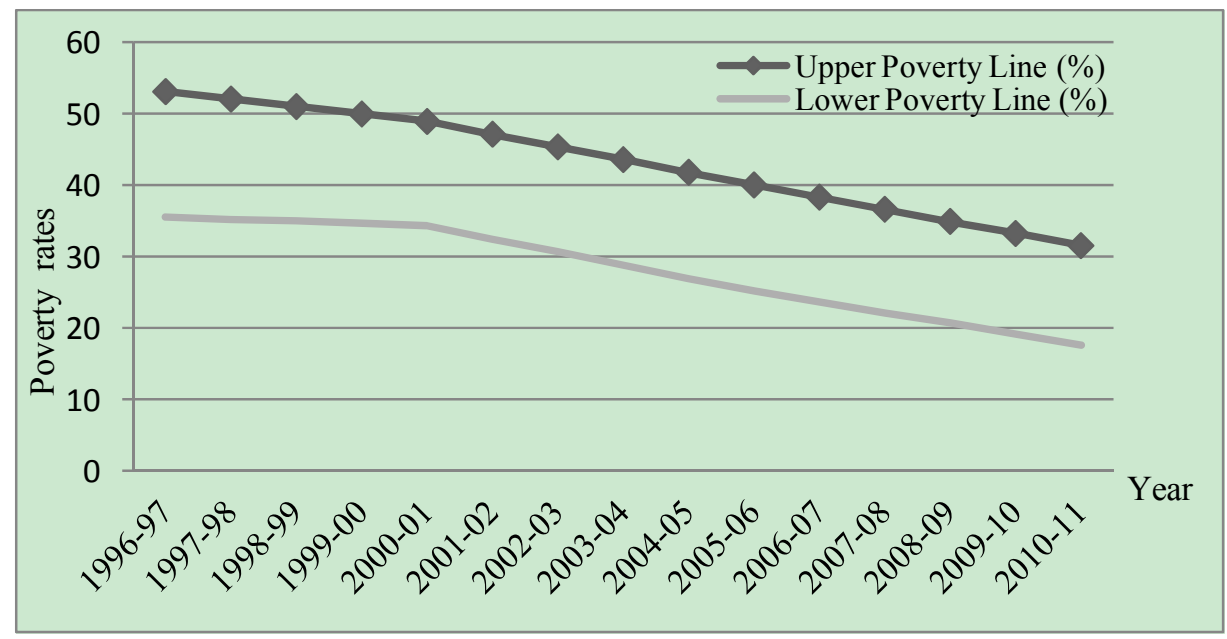

Figure 1. Trend of poverty rates in Bangladesh

\section{Social Safety Net (SSN) Programs in Bangladesh}

In Bangladesh, SSN program was introduced after Bangladesh gained its independence in 1971. The SSN term in general is related to a group of public or community programs with the intention of mainly paying attention on the less privileged and more defenseless people (Paitoonpong, Abe, \& Puopongsakorn, 2008). The SSNs program are planned to provide inhabitants with some cash, access to schooling, improve treatment facilities otherwise assistance for individuals with corporeal or psychological disabilities, elderly, and to those who are living in circumstances wherever they are in danger otherwise neglected (Vivin, 1994). SSNs programs in Bangladesh are mostly publicly provided. Nevertheless, there are also private SSNs that include inter household transfers, personal holy donation, personal donations to NGOs, community support arrangements, along with the other type of charity.

Public SSNs programs are created and established by the different department and officials of government that must turn those policies and steps into accomplishment. The SSNs programs are located in the wide context of three interconnected area of government policy: economic, social and additional government policies. Accordingly, the SSNs programs include a numerous programs and actions establishing by a government that includes extreme poor, disable, elderly, and vulnerable people. Social policy is characterized as a group of public actions connected to community action and individuals' condition, families, and the society or organizations in which they function with the facilities of physical wellbeing, shelter, education, work, furthermore social assurance. On the other hand, economic policy is defined as government policy including business, financial, fiscal, monetary, tax, and commerce policy. Other policies concentrate on the entire additional public measures with public work and policy influence every part of humanity as well as persuade health, housing, resources, assets, income, job, retirement, security, in addition access to schooling and further opportunity.

Grosh et al. (2008) pointed out that SSNs programs are able to assist to accomplish mainly 4 general goals that could be sequentially aim of poverty reduction. Firstly, SSNs programs have an instant effect on reducing 
inequality and hardcore poverty, secondly, facilitate poor family for better investment in nearer future, thirdly, assist targeted poor households to manage various risk like natural or idiosyncratic risks, and fourthly, assist the governments to formulate useful economic reforms. Thus, SSNs programs might be associated with poverty reduction and prevention. It is argued that SSNs are essential to target people with low incomes or in crisis to give temporary assistance or otherwise on a longer tome base. And this is supplemental income transfers for destitute citizens like older citizen, poorer households in the company of kids or disable.

The SSNs programs of Bangladesh consist of following:

1) Cash transfers: Cash transfer programs include the provision of assistance in the form of cash to the poor. In Bangladesh, common cash transfer programs are Old Age Allowances, Allowance for Widowed, Deserted and Destitute Women, Allowance for Retard/Disable Person, Primary Education Stipend Project, Female Secondary School Assistance Program Honorarium Program for the Insolvent Freedom Fighters, and others.

2) In-kind transfer: The main in-kind transfers programs in Bangladesh include food and other food-based programs such as vulnerable group feeding (VGF) program, Food for Works, vulnerable group development (VGD), Test relief (TR), food for work, community nutrition program, and Gratuitous Relief.

3) Subsidy on prices: subsidy for fertilizer and electricity, subsidy for marginal farmer to cope with fuel price hike, and food subsidy like Open Market Sale (OMS).

4) Labor-intensive based public works: 100 days Employment Generation Program, Rural Employment Opportunities for Public Assets and others.

5) Fee waivers: health card, free schooling at primary and secondary level.

6) Other Special programs: Microcredit for Women Self-employment, Housing for the Homeless, rehabilitation program for beggars and alternative employment project for baggers.

The government of Bangladesh has taken dedication to minimize the deprivation of the hardcore poor and vulnerable community. Consequently, the governments allot more funds each year from its non-development budget to put into action regionally and nationally about 84 SSN program. While continuing with the current programs, the existing government implements new program as well so as to contribute to the welfare of the poor and also the needy community. Side by side, the government has also revived the micro-credit programs to further expand the SSN programs for poverty reduction through NGOs and micro finance institutions.

The Government spending on unconditional cash transfer programs like Old Age Allowance, Allowance for Widowed and Destitute Women, and Disability Allowance has been increasing. In FY 2007-08 about 33 per cent in payments has been increased on SSN programs over the earlier budget. In FY 2009-10, the government allocated about US\$ 300 million as a supplementary fund for food-based SSNs program. In addition, the government has planned to extend the SSNs programs by means of increasing the beneficiary's number, amount of benefit support as well.

\section{Data and Methodology}

Data for the analysis are collected from different issues of Bangladesh Economic Review (BER), World Bank report, and Household Income and Expenditure Survey (HIES) 2010 report. Government expenditure data for the period of 1996-2010 are collected from two main sources that are Bangladesh Development Series-Paper No.9 and Unnon Summunny, Bangladesh. This paper gives attention to the expenditure for publicly funding safety net programs. Poverty related data is collected from Bangladesh Bureau of Statistics (BBS). Generally, the BBS is conducted survey at national level each five years. Then data are transformed into linear interpolation for getting yearly data. Data analysis involves many steps. First, scatter plot is drawn, than simple OLS estimation is performed followed by Engle-Granger two-step estimation to determine cointegration.

\section{Relationship between Poverty Rates and SSN Expenditure}

Since 1996, money spent on SSN has increased as shown in Figure 2. That appears to be a relatively small increase from 1996-97 to 2006-07 after which there is a dramatic increase on SSN expenditure that reaches a peak of 2,468.22 million US dollars. In fact, the budget of FY 2006-07 was the last budget of the ruling government in that time. Based on the political consideration and the target for the general election, government allocates more share of budget for SSNs programs. After that, caretaker government, non-political, came to the power for two years. Then the expenditure on SSN decreases of approximately 695.18 million US dollars. In 2009, again another political party forms government and allocated more budgets for SSN for next consecutive years. As the poverty rates have shown some decline over the years, as shown in Figure 1, question arises on whether the high expenditure on SSN negatively correlated with the poverty rates? In answering this question, we proceed by 
examining the SSN as percentage of GDP and SSN as percentage of national budget.

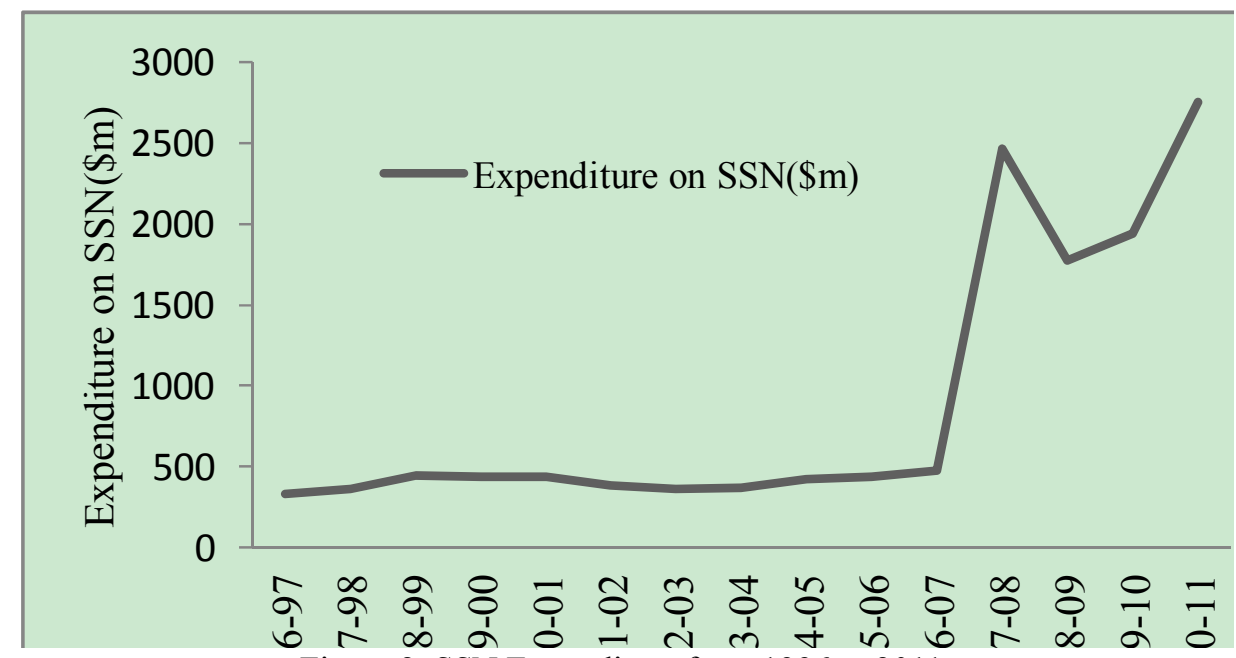

Figure 2. SSN Expenditure from 1996 to 2011

Figures 3 and 4 indicate a negative relationship between the upper poverty rate as well as SSN spending as percentage of GDP and between the lower poverty rate and SSN expenditure as percentage of GDP. According to Barrientos (2011), a SSN programs could be able to be useful if there is a negative relationship between poverty and spending on SSN. Therefore, our simple scatter plot implies that as expenditure allocated for SSN increases, poverty rates decreases. The population falls under the upper poverty rate is the group of population who benefits most from higher expenditure on SSN.

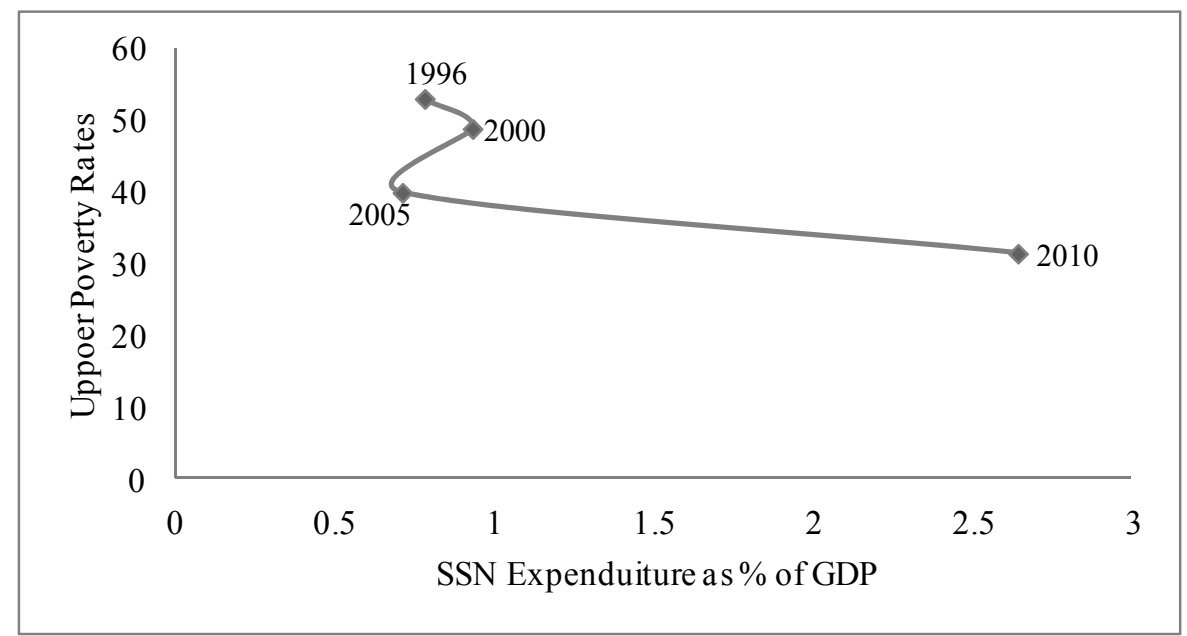

Figure 3. Relationship between upper poverty rates and SSN expenditure as percentage of GDP 


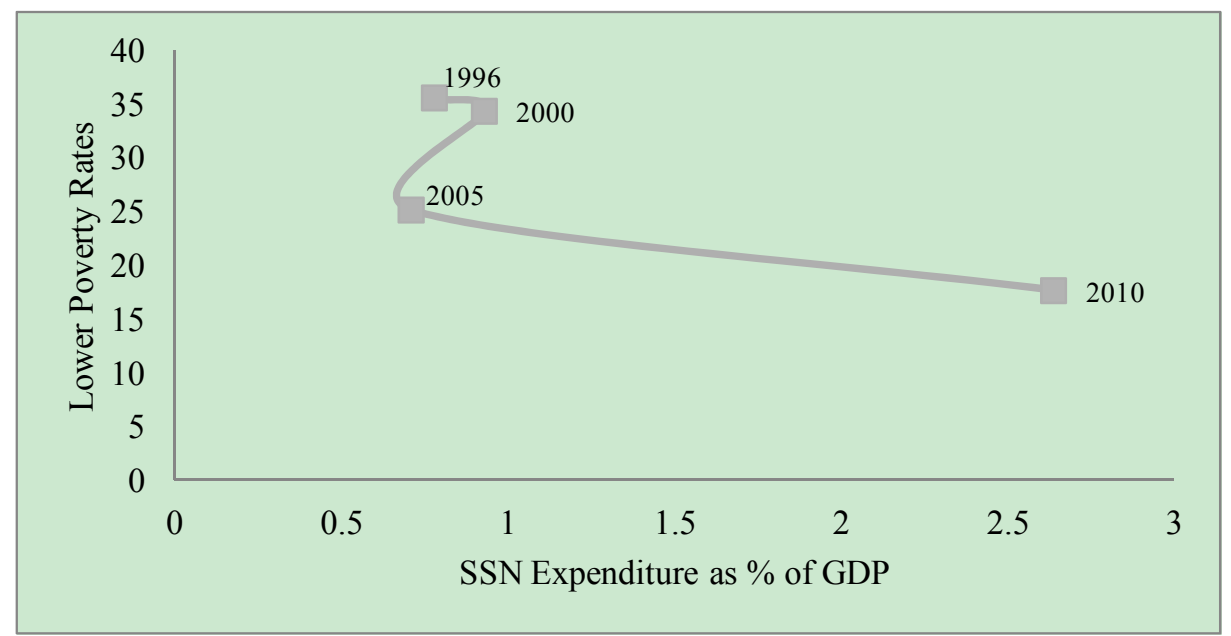

Figure 4. Relationship between lower poverty rates and SSN expenditure as percentage of GDP

When the poverty rates (upper and lower poverty rates) are plotted against SSN expenditure as a percentage of the national budget, negative relationships of the two are more prominent as shown in Figures 5 and 6. Similar to plotting poverty rates against SSN expenditure as percentage of GDP, a higher SSN expenditure means a lower poverty rates. The figures also indicate that the population living under the upper poverty lines benefits more from higher expenditure of SSN as a percentage to the national budget. To given a more vivid negative relationship between the poverty rates (upper and lower poverty rates) with the outlay of SSN as a \% to the national budget, this study proceeds with using the expenditure of SSN as percentage to the national budget in our regression analysis.

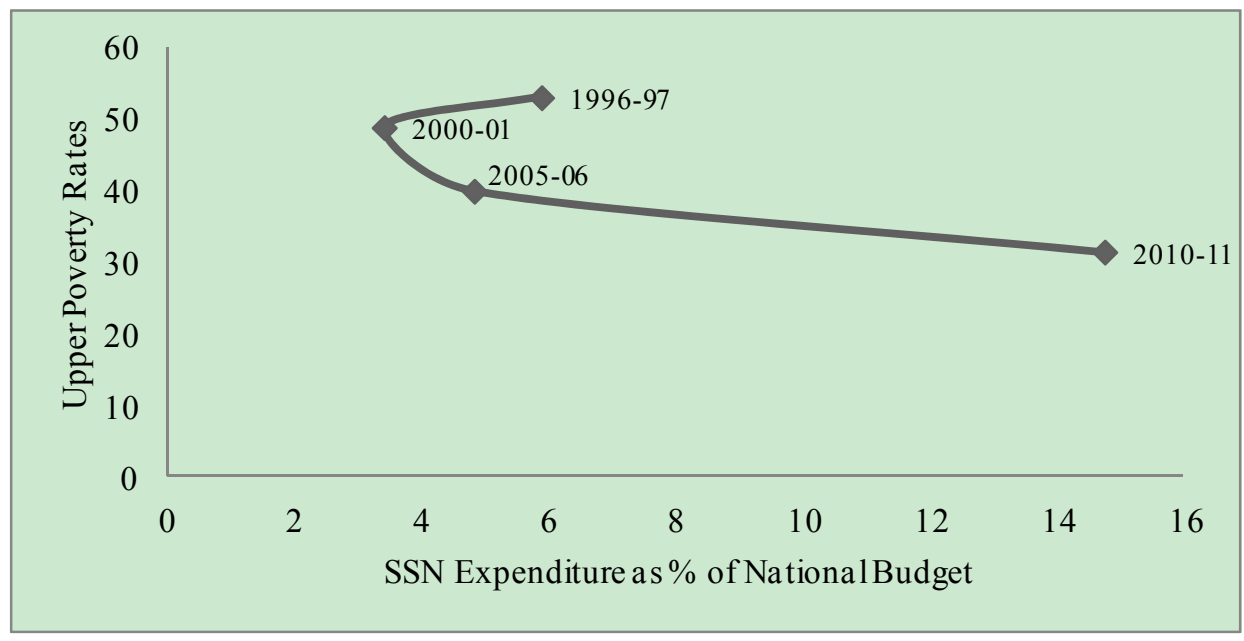

Figure 5. Relationship between upper poverty rates and SSN expenditure as percentage of national budget 


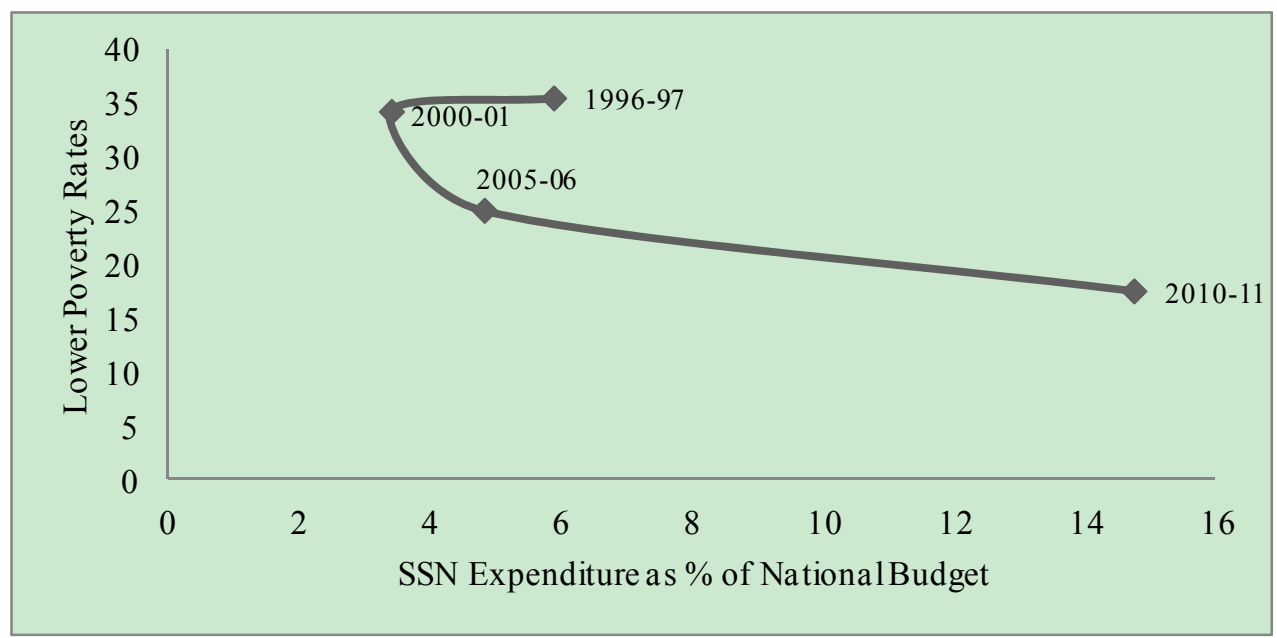

Figure 6. Relationship between lower poverty rates and SSN expenditure as percentage of national budget

To further support our graphical analysis, we employed a simple regression analysis (equation 1 and equation 2) prior to employing a more rigorous analysis to understand the relationship between SSN expenditure as percentage of national budget with the poverty rates (upper and lower poverty rates). The coefficients of the SSN expenditure as percentage of national budget is negative, confirming our graphical analysis that higher SSN expenditure decreases poverty rates, and more prominent for the population living under the upper poverty rates.

The simple linear regression models are

$$
\begin{aligned}
& U P L_{t}=\alpha_{1}+\beta_{1} S O E X_{t} \\
& L P L_{t}=\alpha_{2}+\beta_{2} S O E X_{t}
\end{aligned}
$$

The estimated results are presented in the Table 3.

Table 3. Results of linear regression models

\begin{tabular}{llllllll}
\hline Dependent variable- UPL & Coefficient & Std. Err. & $\mathrm{t}$-value & $\mathrm{P}>|t|$ & $95 \%$ Conf. interval & Adj. $\mathrm{R}^{2}$ \\
\hline SOEX & $-1.108^{* *}$ & 0.3171 & -3.50 & 0.004 & -1.7941 & -0.4236 & 0.444 \\
Constant & $51.26^{*}$ & 2.699 & 18.99 & 0.000 & 45.4303 & 57.0933 & \\
Dependent variable- LPL & & & & & & & \\
SOEX & $-1.032^{*}$ & 0.2710 & -3.81 & 0.002 & -1.6185 & -0.4474 & 0.4914 \\
Constant & $35.657^{*}$ & 2.3066 & 15.46 & 0.000 & 30.6747 & 40.6411 & \\
\hline
\end{tabular}

Note: $*$ indicates $1 \%$ level of significance, $* *$ indicates $5 \%$ level of significance, $* * *$ indicates $10 \%$ level of significance. UPL $=$ Upper Poverty Line, LPL $=$ Lower Poverty Line, SOEX $=$ Spending on SSN as $\%$ of national budget.

As we are using time series data, the above results could lead to spurious regression. A meaningful regression is possible if the variables are cointegrated. We therefore perform the Engle Granger two-step estimation procedure to identify the presence of cointegration by first estimating the regression equation using OLS, in which residuals of the regression equation is estimated. The second estimation involves testing unit root on the residuals. If the null hypothesis of a unit root is rejected, then there is evidence on the presence of cointegration.

The residuals obtain from equations 1 and 2 are

$$
\begin{gathered}
\hat{e}_{1 t}=U P L_{t}-51.26-1.108 \text { SOEX } X_{t} \\
\hat{e}_{2 t}=L P L_{t}-35.65-1.03 \text { SOE } X_{t}
\end{gathered}
$$

The Augmented Dickey Fuller (ADF) test is performed on the following equations (test statistic in parenthesis and more information is presented in Table 4)

$$
\begin{aligned}
\Delta \hat{e}_{l t}= & -0.775 \hat{e}_{1 t-1}-0.263 \Delta \hat{e}_{1 t-1} \\
& (-1.808) \\
\Delta \hat{e}_{2 t}= & -0.583 \hat{e}_{2 t-1}-0.42 \Delta \hat{e}_{2 t-1}
\end{aligned}
$$

\section{$(-1.594)$}


Table 4. Estimated and critical value of Dickey Fuller test

\begin{tabular}{|c|c|c|c|c|c|c|}
\hline & $\begin{array}{l}\text { Test statistics } \\
\mathrm{z}(\mathrm{t})\end{array}$ & $\begin{array}{l}\text { Critical } \\
\text { value (1\%) }\end{array}$ & $\begin{array}{l}\text { Critical value } \\
(5 \%)\end{array}$ & $\begin{array}{l}\text { Critical value } \\
(10 \%)\end{array}$ & $\begin{array}{l}\text { MacKinnon } \\
\text { p-value }\end{array}$ & $\begin{array}{l}\text { Number of } \\
\text { observation }\end{array}$ \\
\hline Equation 5 & -1.808 & -3.750 & -3.000 & -2.630 & 0.3767 & 13 \\
\hline Equation 6 & -1.594 & -3.750 & -3.000 & -2.630 & 0.4867 & 13 \\
\hline
\end{tabular}

Since the test statistics for both residuals (Equation 5 and 6) are statistically insignificant, we cannot reject the null hypothesis of a unit root, and conclude that the residuals are nonstationary. Regression equation without constant and with a time trend has been estimated the same way but result shows no significant differences. Non-rejection of the null hypothesis of a unit root implies that poverty rates and SSN expenditure as a percentage of national budgets are not cointegrated. This finding could be attributed to many reasons including the short span of the observations that covers only 15 observations, and the fact that public spending on SSN is a split part of the entire social security expenses. Expenses on other social protection programs, such as inter-household transfer, support from community, and different type of assistance based on religion view as pointed out by Grosh et al. (2008) are excluded because of the non-availability of data.

To further understand the relationship between poverty rates (upper and lower rates of poverty) and SSN spending as a $\%$ of national budget a VAR analysis is performed using the following equations and results are presented in Table 5. Estimated result for equation (7) shows that $\Delta \mathrm{UPL}_{\mathrm{t}}$ is significantly positively associated to its own past value ( $\triangle \mathrm{UPL} \mathrm{t}_{\mathrm{t}-1}$ ) and equation (9) demonstrates that $\Delta \mathrm{LPL}_{\mathrm{t}}$ is positively associated to its own past value $\left(\Delta \mathrm{LPL}_{\mathrm{t}-1}\right)$ as well. It means that changes in the past year's poverty rate influence to change the current year's poverty rate positively. Conversely, $\Delta \mathrm{UPL}_{\mathrm{t}}$ and $\Delta \mathrm{LPL}_{\mathrm{t}}$ is insignificantly positively related to the past year's change in SSN expenditure $\left(\Delta \mathrm{SOEX}_{\mathrm{t}-1}\right)$. It means that the increase in the previous year's SSN expenditure cannot increase the change in the current year's poverty rate. Results for equation (8) and (10) show that changes in the current year's SSN expenditure $\left(\triangle \mathrm{SOEX}_{\mathrm{t}}\right)$ is negatively insignificantly related to the change in the past year's SSN expenditure $\left(\Delta \mathrm{SOEX} \mathrm{t}_{\mathrm{t}-1}\right)$ and the change in the previous year's poverty rate $\left(\Delta \mathrm{UPL}_{\mathrm{t}-1}\right.$ or $\left.\Delta \mathrm{LPL}_{\mathrm{t}-1}\right)$. Conversely, we can say that the change in past year's poverty rate require higher SSN expenditure in the current year.

$$
\begin{gathered}
\Delta U P L_{t}=\alpha_{10}+\alpha_{11} \Delta U P L_{t-1}+\alpha_{12} \Delta S O E X_{t-1} \\
\Delta S O E X_{t}=\alpha_{20}+\alpha_{21} \Delta S O E X_{t-1}-+\alpha_{22} \Delta U P L_{t-1} \\
\Delta L P L_{t}=\alpha_{30}+\alpha_{31} \Delta L P L_{t-1}+\alpha_{32} \Delta S O E X_{t-1} \\
\Delta S O E X_{t}=\alpha_{40}+\alpha_{40} \Delta S O E X_{t-1}+\alpha_{40} \Delta L P L_{t-1}
\end{gathered}
$$

\begin{tabular}{|c|c|c|c|c|c|c|c|}
\hline$\Delta \mathrm{UPL}_{\mathrm{t}}$ for Equ. 7 & Coefficient & Std. Error. & $\mathrm{t}$ & $\mathrm{p}>|t|$ & \multicolumn{2}{|c|}{ [95\% Conf. Interval] } & Adj. $R^{2}$ \\
\hline$\Delta \mathrm{UPL}_{\mathrm{t}-1}$ & $0.775^{* *}$ & 0.1905 & 4.07 & 0.002 & 0.3505 & 1.1999 & 0.5828 \\
\hline$\Delta \mathrm{SOEX}_{\mathrm{t}-1}$ & 0.012 & 0.0215 & 0.56 & 0.589 & -0.0359 & 0.0599 & \\
\hline Constant & -0.402 & 0.2905 & -1.38 & 0.196 & -1.0495 & 0.2451 & \\
\hline \multicolumn{8}{|l|}{$\Delta \mathrm{SOEX}_{\mathrm{t}}$ for Equ. 8} \\
\hline$\Delta \mathrm{SOEX}_{\mathrm{t}-1}$ & -0.272 & 0.2806 & -0.97 & 0.355 & -0.8974 & 0.3533 & 0.1370 \\
\hline$\Delta \mathrm{UPL}_{\mathrm{t}-1}$ & -4.748 & 2.4700 & -1.92 & 0.083 & -10.2522 & 0.7550 & \\
\hline Constant & -6.420 & 3.8055 & -1.69 & 0.122 & -14.9000 & 2.0585 & \\
\hline \multicolumn{8}{|l|}{$\Delta \mathrm{LPL}_{\mathrm{t}}$ for Equ. 9} \\
\hline$\Delta \mathrm{LPL}_{\mathrm{t}-1}$ & $0.692^{* *}$ & 0.1869 & 3.71 & 0.004 & 0.2762 & 1.1094 & 0.5122 \\
\hline$\Delta \mathrm{SOEX}_{\mathrm{t}-1}$ & 0.006 & 0.0360 & 0.16 & 0.878 & -0.0746 & 0.0860 & \\
\hline Constant & -0.516 & 0.3746 & -1.38 & 0.199 & -1.3499 & 0.3195 & \\
\hline \multicolumn{8}{|c|}{$\Delta \mathrm{SOEX}_{\mathrm{t}}$ for Equ. 10} \\
\hline$\Delta \mathrm{SOEX}_{\mathrm{t}-1}$ & -0.009 & 0.2487 & -0.04 & 0.971 & -0.5634 & 0.5450 & 0.0187 \\
\hline$\Delta \mathrm{LPL}_{\mathrm{t}-1}$ & -1.874 & 1.2896 & -1.45 & 0.177 & -4.7486 & 0.9986 & \\
\hline Constant & -1.67 & 2.5844 & -0.65 & 0.533 & -7.4290 & 4.0878 & \\
\hline
\end{tabular}

Table 5. Estimated results for VAR model

$*$ indicates $1 \%$ level of significance, $* *$ indicates $5 \%$ level of significance, $* * *$ indicates $10 \%$ level of significance. 


\section{Conclusion}

Expenditure on SSN in Bangladesh over the period of 2006 - 2011 has shown an increasing trend and at the same time poverty rates over the same period have also declined. A scatter plot and simple regression analysis indicate a negative relationship between the two. This implies that poverty rates reduction requires rigorous spending on SSN. Results also indicate that the reduction in poverty rates is apparent for the population living under the upper poverty rates. Nevertheless, using the Engle Granger two-step estimation, we cannot conclude that cointegration among the variables exist. In addition to short span of observations, other SSN expenditure such as NGOs and other private SSN transfers like charity, remittance are not included. Thus, a small part of SSN expenditure may not produce vigorous evidence (Grosh et al., 2008).

As a disaster prone country, a huge number of people are affected by natural disaster every year. Consequently most of them fall into poverty situation, particularly who live in rural area. Thus the number of existing poor is still larger (about 45 and 25 million are poor and hardcore poor, respectively). With the improvement of the social indicators such as literacy rate, infant mortality rate, life expectancy, per capita income, income inequality remains as a vital problem. Accordingly bottom level people of the country are more vulnerable.

Realizing the facts, the government of Bangladesh has been trying to mitigate the poverty situation since its independence in 1971. As a developing country; Bangladesh has inadequate ability to increase more SSN outlay, as it needs. Limited resource is a key obstacle to the extension of SSN. Nevertheless a broader perspective for short-run and long-run on SSN is desirable to reduce the poverty rates more effectively. The short-run assistance is needed to protect the individual and households affected by shocks. The long-run assistance is needed for protecting the poor households' consumption as well as improving their productive power. As any assistance (cash or in-kind) transfer to the poor households or individuals enter into the basket of household resources, they could be used for either consumption directly or more productive purposes, and both. Deprived and vulnerable people mostly put effort to invest in small business and other earnings activities to augment the value of transfer; even they receive a small amount transfer. While the poor people or household receive additional earnings or money, most of them usually spend that received cash locally, for the purpose of foodstuff, clothes, or inputs buying. This process stimulates the local economy. So SSNs programs have larger prospective to contribute to poverty reduction. However, the massive poverty situation of Bangladesh might not be worked out by SSNs program simply. It is moreover called for the adaptation of social as well as economic enlargement programs and policies that renovate production, stimulate economic growth, and generate earnings based working opportunity on a considerable level.

\section{References}

Bangladesh Bureau of Statistics BBS. (2011). Preliminary Report on Household Icome and Expenditure Survey -2010. Statistics Division, Ministry of Planning, Bangladesh.

Barrientos, A. (2011). Social protection and poverty. International Journal of Social Welfare, 20(3), 240-249. http://dx.doi.org/10.1111/j.1468-2397.2011.00783.x

Barrientos, A., Hulme, D., \& Shepherd, A. (2005). Can social protection tackle chronic poverty? The European Journal of Development Research, 17(1), 8-23. http://dx.doi.org/10.1080/09578810500066456

Devereux, S. (2002). Can social safety nets reduce chronic poverty? Development Policy Review, 20(5), 657-675. http://dx.doi.org/10.1111/1467-7679.00194

Finance Division FD. (2009). Bangladesh Economic Review 2009. Ministry of Finance, Bangladesh. Retrieved April 5, 2011 from http:/www.mof.gov.bd/en

Finance Division FD. (2010). Bangladesh Economic Review 2010. Ministry of Finance, Bangladesh. Retrieved April 5, 2011, from http:/www.mof.gov.bd/en

Finance Division FD. (2011). Bangladesh Economic Review 2011. Ministry of Finance, Bangladesh. Retrieved April 5, 2011, from http:/www.mof.gov.bd/en

Finance Division FD. (2012). Bangladesh Economic Review2012. Ministry of Finance, Bangladesh. Retrieved from http:/www.mof.gov.bd/bn

Grosh, M. E., Del Ninno, C., Tesliuc, E., \& Ouerghi, A. (2008). For Protection and Promotion: The design and implementation of effective safety nets. Washington, D.C: The World Bank. http://dx.doi.org/10.1596/978-0-8213-7581-5 
Hulme, D., Hanlon, J., \& Barrientos, A. (2010). Just give money to the poor : the development revolution from the Global South. Sterling, VA, USA: Kumarian Press.

Kenworthy, L. (1999). Do Social-Welfare Policies Reduce Poverty? A cross National Assement. Social Forces, $77(3), 1119-1139$.

Mahmud, H. (2008). Unintended consequences of micro-credit in Bangladesh: an evaluation from human security perspective. Asian Social Science, 4(10), 127-131.

Paitoonpong, S., Abe, S., \& Puopongsakorn, N. (2008). The meaning of “social safety nets". Journal of Asian Economics, 19, 467-473. http://dx.doi.org/10.1016/j.asieco.2008.09.011

Rahman, H. Z., Choudhury, L. A., \& Ali, K. S. (2011). Social Safety Nets in Bangladesh (Vol. 1). Dhaka: Power and Participation Research Centre.

Ravallion, M., \& Sen, B. (1996). When method matters: Monitoring poverty in Bangladesh. Economic Development and Cultural Change, 44, 761-792. http://dx.doi.org/10.1086/452244

Slater, R. (2011). Cash transfers, social protection and poverty reduction. International Journal of Social Welfare, 20(3), 250-259. http://dx.doi.org/10.1111/j.1468-2397.2011.00801.x

Vivin, J. (1994). Social safety nets and adjustment in developing countries. Geneva: United Nations Research Inststitute for Social Development(UNRISD). 